\title{
American Dream or Avaratia: Critical Circumspectis of American Dream Through Ages
}

\author{
Faiza Zaheer ${ }^{1} \&$ Kamal ud Din ${ }^{2}$ \\ ${ }^{1}$ Department of English Language\& Literature, University of Management \& Technology, Lahore, Pakistan \\ ${ }^{2}$ Department of English Language \& Literature, Forman Christian College University, Lahore, Pakistan \\ Correspondence: Faiza Zaheer, Department of English Language \& Literature, University of Management \& \\ technology, Lahore, Pakistan. E-mail: faizazaheer76@gmail.com
}

\author{
Received: February 11, 2019 Accepted: March 4, 2019 Online Published: April 6, 2019 \\ doi:10.5539/ijel.v9n3p57 URL: https://doi.org/10.5539/ijel.v9n3p57
}

\begin{abstract}
This paper is an attempt to apply Jacques Derrida's theory of Deconstruction to American Dream and its treatment in the language of Edward Albee's play American Dream and other American Playwrights. Different deconstructive terms have been applied to understand and analyze the language of Albee's The American Dream. Deconstructive terms; Différance, Erasure and Aporia have been applied to the language used by Albee to analyze the concept of American dream and its relation to its context of old American Dream as envisaged by the founding fathers and the new American Dream as defined by James Truslow Adams. These deconstructive terms will help readers to understand the themes and language of postmodern and post war American drama in general and those of Albee's in particular. This, in turn, makes the reader realize that American dream as depicted in modern American Playwrights is materialistic, illogical, futile and bizarre: Albee's play reflects modern American society and its sensibility. Language of modern is simple yet it communicates multi-faceted interpretations and those interpretations have been explored in the light of all these deconstructive terms. The basic purpose of involving these deconstructive terms in analyzing the language of Albee's The American Dream and the other major postmodern American plays is not only to understand the mutability and fluidity in the diction but also to expose absurdity and apparent meaninglessness in it.
\end{abstract}

Keywords: deconstruction, American dream, individual, language, illogical, futile

\section{Introduction}

American Dream for the postmodern American Society has been a source of inspiration, motivation and stimulation. American people believed this, loved this, adorned this yet they were unable to realize, comprehend and attain this. This misjudgment of Dream (my italics) turned American people towards a blind alley where their spiritual blindness made them miserable and wretched. American people were themselves not sure about their existence and reality. Dream itself was enchanting and captivating and no doubt was based on reality and truth, but with the passage of time this Dream started losing its significance and implication as people took it to fulfill their materialistic and money-oriented goals and objectives. American Dream had been firstly celebrated and appreciated and then depreciated and downgraded in American Literature. Dream once was the source of inspiration but after losing its grace and meaning it was reduced to materialism. As Sam Shepard (2000) comments on American Dream:

I don't know what the American Dream is. I don't know it does not work Not only doesn't it work, the myth of American Dream has created extraordinary havoc, and it's going to be our demise........this notion that not only were we given this land by God somehow, but that we're entitled to do whatever we wanted to with it, regardless of the consequences, and reap all the fortunes out of the land, much to the detriment of everyone else ......this rampant puritanical class of European Colonialism .......behind the whole thing is land-hungry Europeans wanting to dominate (p. 38).

This is what the reality of American Dream is as it exposes the spiritual chaos of American society and American culture. American Dream is a havoc (my italics), destruction, devastation and deprivation. This is the manifestation of the dominance of materialism over the purity, history and limpidness of American Dream. Concept of "free land" is no more than a cliché and this cliché is misused as people are blindly following this 
misinterpretation of American Dream. American Dream is the demise of American society, culture and ethics. Anguish, distress, estrangement and meaninglessness have become the dominant components of American society as American Dream has lost its importance. The same concern Edward Albee expounds in his play The American Dream as Nicholas Canaday, Jr. delineates this in his article Albee's The American Dream and the Existential Vacuum, "Edward Albee's plays are ferocious attacks on lethargy and complacency in American Society" (1966, p. 12). Canady also comments that Edward Albee's plays are "a savage denial that everything is just dandy" (1966, p. 18). American Dream has been turned from aspiration into chaos that has pervaded the whole society. Canaday has mentioned in her article that American Dream according to Albee has become ineffective, hopeless and weird. American Dream has been decentralized and collapsed and this has been reduced to a caricature and false impression of American Society, culture and morality. As O'Neill laments on the spiritual emptiness of American Dream in one of the press conferences in 1946:

..... A sort of unfair non sequitur as though events, as though life, were being manipulated just to confuse us. I think I'm aware of comedy more than I ever was before; a big kind of comedy that doesn't stay funny very long (p. 123).

\subsection{Research Question}

How can one investigate into the evolution of the concept of American Dream in the American Society through Derridean Deconstructive study of plays of Edward Albee and the other major post war and postmodern American Playwrights?

\subsection{Research Objectives}

1) To reassess the American Dream to bring out the different interpretations.

2) To investigate into the disorder, confusion and degeneration exposed by 20th century American Drama.

3) To analyze the language used by American playwrights in their plays.

4) To explore the open-endedness of language by involving the Derridean Theory of Deconstruction.

5) To apply important deconstructive terms to the language used by American playwrights in their plays to explore and analyze postmodern and post war American diction.

\section{Methodology}

Qualitative research style will be followed along with the literary and linguistic criticism on Edward Albee's play The American Dream. In this research, Jacques Derrida's Theory of Deconstruction will be applied to Edward Albee's play The American Dream and other modern American plays. Deconstruction theory holds this point of view that language is fluid and flexible and it can be understood and comprehended according to the situation and circumstances in which it is spoken and communicated. Various characteristics of Deconstruction theory will be applied to the language Edward Albee used in The American Dream to expose the paradox within the American Dream to highlight the disorder, chaos and disintegration within the postmodern American society. The components of Deconstruction Theory which will be used in this research are Aporia that reveals undecidability and the inherent contradictions found in any text, Différance which focuses on the multiplicity of meanings, and Erasure that discloses the absence of meaning is itself full of meaning. Along with the application of this theory, other plays of Edward Albee and the works of other postmodern American writers, e.g., Sam Shepard, Eugene O'Neil, and Arthur Miller will also be discussed to prove my point of view related to American Dream and Edward Albee's play The American Dream.

\section{Discussion}

Albee and other American playwrights express their grief on the spiritual emptiness and the worthlessness of the existence of American people. American Dream has become something tragic, catastrophic and unattractive and it has been turned to nuisance. This dream has become a dark comedy that has lost its fun, humor and importance. O'Neill's Long Day's Journey into Night exposes the American Dream which had been turned to American Nightmare as characters in this play are lost spirits: Mary is a drug addict and somnambulist; walking between past and present. Whereas Edmund and Jamie are internally empty and last but not the least James Tyrone is a failure in all spheres of life. They are lost souls as Mary admits in front of Edmund (1941):

How could you believe me-when I can't believe myself? I've become such a liar. I never lied about anything once upon a time. Now I have to lie, especially to myself. But how can you understand, when I don't myself. I've never understood anything about it, except that one day long ago I found I could no longer call my soul my own (p. 48). 
This is the revelation and the confession of Mary Tyrone and her disclosure exposes the true identity of American society and American culture. Americans are unable to understand themselves and their situation as they are frustrated, disturbed, annoyed and discouraged. Tyrone belongs to middle class which has to suffer a lot due to the misinterpretation of American Dream. Same frustration can be seen in the other plays of that era where playwrights and characters created by them are unable to explore themselves and they are so frustrated and degenerated that they no longer feel and sense their soul. Mary Tyrone is not getting ostentatious or exaggerated instead she is revealing the true American behavior.

\subsection{Disorder, Chaos and Nothingness and American Playwrights}

Escapist yet confessional is the real American attitude which is not only exposed by Mary Tyrone from Long Day's Journey into Night but also the other characters of that postmodern American era. Blanche and Stella from A Street Car Named Desire by Tennessee Williams as Blanche lives a life of illusion and reality whereas Stella does not believe whatever happened to Blanche she ends up everything by saying this, "I couldn't believe [Blanche's] story and go on living with Stanley" (Williams, 1947, p. 77) and Eunice (her neighbor) reveals the bitterest reality of American society, "Don't ever believe it. Life has to go on. No matter what happens; you've got to keep on going" (Williams, 1947, p. 79). This is the typical American behavior whatever is going on one should not be concerned about this. One should be quite insensitive and thoughtless about the surroundings and the issues going on in surroundings. Blanche, Stella and Stanley all are living in an illusionary world and they are apparently happy with their nameless, meaningless and worthless existence.

This sense of nothingness, worthlessness and barrenness in life are quite common in Edward Albee's plays as they have been written almost in the same era of confusion, disorder and chaos. As Wendell V Harris (1966) delineates this hollowness of American Society in his article:

[Albee] imparts no sense of a cure, the knowledge of paths towards enlargement, not the diminution of life ...... [moreover Albee] attempts to satirize a situation which he sees both painful and irremediable...... [as his work is] largely a negation of the possibility of meaningful human action (p. 65).

This is what the reality of American Dream as that is irrevocable, pungent and bitter as reality is something else and perception is totally different from the perception. Life has lost its meaningfulness rather it has become mechanical. For Albee, American Life is absurd, just like the theatre of the absurd which makes no sense of life and existence. He satirizes the circumstances in which American society is living aimlessly and without purpose and direction. This situation is severe and irredeemable and American society is unable to find its way. For post war and Postmodern American society and people, life is full of bitterness, senselessness, resentments and confusion. They are facing agony, torture and anguish inwardly as well as outwardly. Meaningful human actions, significant and momentous conversation, and life full of aims and objectives are hard to find during that era due to materialism, greed and avariciousness.

\subsection{Open-Endedness of Language, Derridean Theory \& American Dream}

This research paper is a critique on the misinterpretation, misconception, miscommunication and misrepresentation of American Dream through the language used by Albee in his plays particularly in American Dream. Moreover, American Dream has been discussed in terms of deconstructionist point of view. American Dream has been discussed according to different Deconstruction terms as Aporia, Erasure, Différance and contradictions within the Individuals. Deconstruction according to Bloom (1979):

[is] post structuralist theory which was initiated by Jacques Derrida. It is a combination of the word "construction" and "destruction"? Deconstruction does not know however, seek to destroy, rather it points out the limitless instability of language. Deconstruction is a complex process because meaning is contextually determined and since contexts are always changing meaning becomes indeterminate. ...... Deconstruction claims that there can never be a transcendental signified - that is a center to all meaning for which all other language is built upon. We can never, in any instance of speech or written word, have a fixed and decidable present meaning. "There is nothing outside the text" (Derrida) All that we know is constructed of signs in relation to one another. Whatever exists outside the text is a realm in which human comprehension and knowledge do not exist (p. 34).

According to Deconstruction, language does not have a stable meaning; meaning is constructed, destructed, reconstructed and finally deconstructed. Even after having so many steps still meaning does not have one stable interpretation. There are so many interpretations of one analysis and one meaning and this is what Deconstruction is. Deconstruction is to analyze the connotations and subtext of the text and that analysis is undecidable, unstable, unsteady, unsettled and unpredictable. Sign is interpretation and that interpretation is an 
interpretation of many interpretations and even none of them is permanent and that impermanence and transience understanding of connotation is the most important component of Derridean Deconstruction. In this paper, old and new American Dreams and Edward Albee's The American Dream have been discussed in the light of Deconstruction and its important terms; Aporia, Erasure and Différance. The effort has been made to elucidate and criticize the perception of American Dream. As this has been mentioned by Raman Selden (1985):

Derrida claims that deconstruction is something that simply happens. Each text deconstructs itself by undermining its own supposed foundation. To being the deconstruction process we must "locate the moment when a text transgresses the laws it appears to set up for itself (p. 132).

Derrida believes that deconstruction simply happens and that is based on reader's individual perception and insight which varies from person to person. The understanding and perception of American Dream also varies from individual to individual. Texts of different playwrights during post war and postmodern American society reflect the American perception towards American Dream. American Dream which once was celebrated and welcomed during eighteenth and nineteenth centuries has been turned into curse in twentieth century. This is not only the matter of perception but also about the amendments, transformations and conversion of American Dream from Liberty, equality, fraternity and the pursuit of happiness to greed, materialism, selfishness, insensitivity and avariciousness. Derridean Deconstruction exposes this issue how this transformation happened and how this dream has been turned into horrendous and dreadful Dream.

Eugene O'Neill's (1948) perception of American Dream represents the ugliness and repulsiveness of the circumstances which American people were facing during twentieth century:

This country is going to get it-really get it. We had everything to start with-but there is bound to be retribution. We've followed the same selfish, greedy path as every other country in the world. We talk about the American Dream, and want to tell the world about American Dream, but what is that dream, in most cases, but the dream of material things? I sometimes think that the United States, for this reason, is the greatest failure world has ever seen. We've been able to get a very good price for our souls in this country-the greatest price perhaps that has ever been paid (p. 124).

What O'Neill states is that the American Dream has lost its importance, significance and magnitude. American Dream is a failure instead of a success and according to O'Neill that the whole world knows that American Dream is collapsed, malfunction and just a disappointment for the American society and culture. The price that American people have to pay is in terms of losing their self, identity and individuality for materialism, greed and selfishness. Albee's play The American Dream is exposing the same issue that O'Neill has pointed out as Mommy, Daddy, Youngman and Mrs. Barker all of them have sold their souls to greed, selfishness and self-centeredness. They are not even human beings rather they are insensitive and insensible creatures as their actions demonstrate their inner emptiness and shallowness. Mommy and Daddy have the most important roles of parenting yet they are void of all parental feelings, emotions, sincerity and genuineness. Mommy is making fun of Daddy's manliness and Daddy needs confirmation and substantiation all the time from Mommy for his manliness and masculinity. Youngman is strong, well-built and muscular yet he is inwardly weak, shallow and degenerated as he himself does not know what to do in his as he believes that he is incomplete.

This is the situation of postwar and postmodern American society and culture as they have no sense of life and warmth of relationship. American society wastes their life as they are dead to each other and their death is spiritual, metaphorical and symbolic. Albee, in one of his interviews to New York Times, states, "....... I write play about how people waste their lives. People...... have not lived their life; that's why they are screaming and crying out" (Albee, 1967, p. 67). This is what American dream is; people cry and scream and get nothing from this. Albee's The Sandbox shows the same structure of emptiness, bleakness and insensitivity which had been showed and demonstrated in The American Dream. Same characters have appeared in The Sandbox and the same behavior they show this to old people and American Dream. In The American Dream and in The Sandbox, Mommies and Daddies want to get rid of Grandma which is a symbolic and metaphorical presentation of American Dream. Grandma believes that American society has American Dream within itself what it needs to explore it and realize its existence. This is what she asks Youngman to understand and recognize within himself by calling him 'American Dream' yet she realizes that she is not given attention as old people become obsolete objects for younger ones and she states this after being hushed up by Mommy:

There you go. Letting your true feelings come out. Old people aren't dry enough, I suppose. My sacks are empty; the fluid in my eye balls is all caked on the inside an edge, my spine is made of sugar candy. I breathe ice; but don't hear me complain. Nobody hears old people complain because people think that's all 
old people do. And that's because old people are gnarled and sagged and twisted into the shape of a complaint (p. 14).

This is what Grandma makes clear not only to Mommy but to the American society and that is that American Dream has been reduced to empty sacks. American People take American Dream as they treat old people; dumping them into old homes and leaving them on their own. Postmodern American society assumes that American Dream is no more than a complaint.

\subsection{Postmodern America Drama and American Dream}

In Albee's The American Dream, arrangements are being done to send Grandma to old home whereas in The Sandbox, Grandma has been dumped in a sandbox and has been assumed dead as Daddy has orchestra for the ritual. Dumping Grandma in sandbox and sending her to old home represent American Behavior towards American Dream. They want to dump it and forget it yet American people want to use the remains of American Dream for their own vested interests. Mommies, Daddies and Young men are the representation of American society and culture. These American people are the parts of wreck of modern life that has the vested humanistic version of American Dream and they make their life more than havoc. As D.H. Lawrence explains human condition in Lady Chatterley's Lover (1978):

Ours (modern age) essentially a tragic age, so we refuse to take it tragically. The cataclysm has happened, we are among the ruins, we start to build up new little habitats, to have new little hopes. It is rather hard work; there is no smooth road into the future: but we go around or scramble over the obstacles (p. 36).

This is what the reality of modern Americans who live aimless and directionless life and they have no idea of their destinations and objectives. They are tragic characters and they face the destruction, devastation and demolition. The American society faces the tragic end of American Dream in form of its own alienation, hostility, unfriendliness and estrangement. American people find their existence incomprehensible, inexplicable and perplexing as they pretend to be happy yet they are not. They have little hope but those hopes are tarnished with fear and apprehension regarding present as well as future. It seems that the American people are taking revenge from each other. This unseen revenge can easily be seen in Albee's American Dream, Sandbox and Who's Afraid of Virginia Woolf. In The American Dream and The Sandbox, mommies and daddies of both plays want to get rid of Grandma and in this way they are emblematically and symbolically taking revenge from old values as those values are unable to fulfill their present dreams and future hopes. On the one hand, Mommy and Daddy are taking revenge from Grandma and on the other hand Young Man in both plays is taking revenge from their own self (my italics) as both are young, strong, and physically powerful yet have weak will and indecisive power. Grandma tries to make Young Man believe and realize that he is the American Dream yet he is unable to understand what American Dream is. It seems that the American people are trapped in the whirlpool and vortex of existence, survival and circumstances. One can observe this entrapment in Edward Albee's The Zoo Story where Jerry feels himself trapped and ensnared by the situation in which he is living in.

\subsection{The Absurdity and Illogicality of Human Existence and the American Dream}

The absurdity and the illogicality of the existence and being human is quite evident from his behavior when Jerry in The Zoo Story shows his fear that his seat in Central Park Zoo may be snatched by him. On the contrary, Peter is happy with his ordinary life and common life style. Jerry gets perturbed after observing satisfaction and contentment of Peter regarding his married life. Jerry is scared that Peter might occupy his place and he might lose his only belonging. There is a sense of revenge which Jerry wants to take from Peter and the unconscious vengeance and retribution that he is showing towards him. Peter is not an extra ordinary person yet his ordinary life is quite disturbing for Jerry. Jerry gets alarmed by Peter's settled life and he declares, "I've come here for years; I've come hours of great pleasure, great satisfaction, and right here. And that's important to a man. I'm a responsible person, and I'm a GROWN UP. This is my bench and you have no right to take it away from me" (Albee, 1968). As Carolyn E Johnson states this point in her article In Defense of Albee:

Throughout the play there are indications and prevailing overtones of being trapped. At the very end of the play as Jerry dies, he says, "...... Your parakeets are making the dinner......the cats...... are setting the table....." How very absurd! To be subjected and tied to these menials, dull, unstimulating tasks and responsibilities that we make for ourselves. The sad truth is that these things might be bearable if at the same time we could communicate" (Johnson, 1968).

Absurdity at first place is quite evident from the last words spoken by Jerry and according to him life is meaningless, empty and futile. Absurdity of human existence can be easily understood from the communication 
between Peter and Jerry where Jerry is talking meaninglessly and absurdly and he is very much concerned about the place he has in central park. According to Albert Camus:

Absurdity represents the conclusion arrived at those who had assumed the possibility of a total explanation of existence by the mind who discovers instead an unabridged gulf between rationality and existence. Out of this tension between the ways one desires the world to appear and the harsh truth of human existence emerges the metaphor of the absurd. The metaphor of absurd is not exclusively found within the domain of philosophy since it is deeply tied to one's life experience (Camus, 2006).

This paper also focuses on the absurdity of human experience, meaninglessness and illogicality in communication are the major components of discussion in Camus' concept of absurdity and this absurdity is manifested in different plays of Edward Albee. What Camus believes is that individual experience and surroundings play an important role in developing meaninglessness and irrationality in an individual. This is what happened in Albee's The Zoo Story, The Sandbox and The American Dream. This is true that the communication is one of the most important reasons as well as consequences of the failure of American Dream. Albee's plays not only expose the failure of human existence but also show the failure of communication. Mommies, Daddies and the Young men of The Sandbox and The American Dream communicate all the time yet their communication is void of all meaningfulness and significance. Mommies are getting sarcastic towards Daddies and Daddies are unsure of what to do on very trivial and trifling issues as Daddy wants encouragement and moral support from Mommy in opening the door:

Daddy: Was I firm about it?

Mommy: Oh! So firm; so firm;

Daddy: Was I Decisive?

Mommy: So Decisive! Oh, I shivered (Albee, 1961).

Being decisive and being firm are something impossible and impractical for American masculinity. American males are unable to show confidence within them and they are incapable of doing something constructive and creative. In The Sandbox, Mommy is cruel and stupid while Daddy is weak and insipid. Just like The American Dream, Mommy and Daddy in The sandbox are vicious, inhuman and cruel and Mommy talks quite rudely and sarcastically to Daddy when he wants to talk to her, "Well, you can talk, if you want to...if you can think of anything to say...if you can think of anything new" (Albee, 1961). This is not only the failure of communication but it also exposes the meaninglessness and purposelessness of life and existence.

This paper focuses on the emptiness of Mommies and Daddies who are the representation of a squirmy family life where the strongest relationships are the most chaotic and pathetic. They are supposed to strengthen the family and familial relationships yet they are unable to define associations as they are cruel and weird and their behaviors are quite bizarre and ambiguous. In twentieth century American Drama, all the male characters appeared in the plays are mentally incapable, weak and indecisive. Youngman in The American Dream is unsure of his strength and vigor when Grandma tries to make him realize about his power still he does not know what to do:

Youngman: Well, actually, I may have a career there yet. I've lived out on the West Coast almost all my life....... and I've met a few people who.... might be able to help me. I'm not in too much of hurry, though. I'm almost as young as I look. Grandma: Yup. Boy, you know what you are, don't you? You're the American Dream, that's what you are. All those other people, they don't know what they are talking about. You ...... you are the American Dream (Albee, 1961).

Young man does not know his strength as he is void of all enthusiasm and zest which is the hallmark of American youth of postmodern and post war American society whereas Grandma who was the representation of American Dream is trying to make this young man realize that he is the hope for the future of America. Youngman is in search of help rather than realizing, exploring and depending on his own self. This self-realization, self-exploration and self-dependency are the most important components of American Dream. But Young Man is an incomplete American Dream. He is unable to realize his power and looks for some help. The same is the case with other male characters of American Drama of that age where they are directionless and aimless and their life seems quite useless as Tyrones' of Long Day's Journey into Night, Biff and Happy of Death of a Salesman, and the Young man of The Sandbox. All these young men are capable of doing something creative and inventive yet they are not sure of their talents and skills because they do not depend upon themselves. Young man in American Dream feels himself incomplete, imperfect and curtailed, “.... I will be happy to tell you. It's that I have no talents at all, except what you see....my person; my body, my face. In every 
other way I am incomplete, and I must therefore......compensate" (Albee, 1961, p. 44). This is what Young man thinks of himself that he is incomplete and he has no idea about his past, present or future. In other words, he is an incomplete American Dream as he has lost his twin. Twin in Albee's American Dream exposes the harsh and ruthless reality of American Dream is that this has been mutilated, and disfigured by the people who should have strengthened and reinforced this dream. This Dream which promised American people of prosperity, success, happiness and contentment only when they depend upon themselves has been turned into something impossible and unattainable.

It seems that the American Dream has lost its twin which has another name of self-realization, self-exploration and self-dependency. In The American Dream, Young man feels him incomplete because his twin has been taken away and he has no feelings and emotions towards anything he comes across in his life. This is the inner feelings of Youngman which he delineates before Grandma where he expresses his sorrow and grief over losing his twin when he was very young:

......We were torn apart......I have suffered losses......that I can't explain. A fall from grace....... departure of innocence......loss......loss.......since then........ I no longer have the capacity to feel anything. I have no emotions. I have been drained from asunder...... disemboweled. I have, now, only my person.......my body, my face...... I cannot relate... I know I must be related to as I told you, I am incomplete......I can feel nothing. I can feel nothing. And so...... here I am......And it will always be thus (Albee, 1961, p. 67).

This is what Youngman wants to express in front of Grandma that he has fallen from grace and lost his innocence. American people have lost that spirit which means they have lost their twin. They have lost innocence and due to all this America has become no man's land. This statement has revealed the sad human plight in America:

Is it true, young man, that you are now an inhabitant of no-man's land, on the one side shunned and disowned by your brethren, and on the other an object of contempt and derisions to your betters? Is that your problem, son (Albee, 1959, p. 24)?

Though this hopeless and miserable situation delineates the racist issues in America yet it also pinpoints the current American situation as values and morality has become an object of derision, disdain, mockery and condescension. American Dream has been disowned and rejected by American people; people who once used to believe in self-realization, self-exploration and self-reliance. Metaphorically, American land has become no man's land for all those people who sincerely followed the American Dream.

This is the fate of American society and culture which has to be faced and experienced by American people. Desperation, disintegration, bleakness and barrenness which have been delineated by post war and postmodern American playwrights are the darkest features of American Dream. As Young man realizes his situation in the modern world and he takes his existence meaningless and directionless. He has lost his strength and vigor in form of his twin and he is feeling himself forlorn and despondent. That's why Grandma points out that she has seen someone just like him, "I was mistaken...... before. I don't know you from somewhere, but I knew...... once...... someone very much like you...... or, very much as perhaps you were (Albee, 1961). This is what Grandma observes in Youngman that she has seen somebody just like him. Youngman's twin had been mutilated by Mommy and Daddy years ago and the memory of this twin comes to Grandma and her feeble memory tries to relate this young man to his twin and that is the lost American Dream which has been mutilated by people like Mommies, Daddies and Mrs. Barker who knowingly and unknowingly destroy the roots of American spirit and strength. This is ironic that Young man makes a point to Grandma whatever he is saying might be fake, "Be careful; be very careful. What I have told you may not be true (Albee, 1961, p. 115). This dialogue of Youngman reveals the ambiguity and uncertainty in his behavior and words and this is related to the deconstructive term Aporia which explores ambiguity in the text. Aporia means impassable which makes meaning ambiguous and self-contradictory and this is what Young man is doing- he is vague, weird and paradoxical. This paradox, self-contradiction and ambiguity are not only the characteristic of the modern world but also demarcate the conditions of American society. According to Aporia, the main aim is not to solve ambiguities but to explore ambiguity as well as doubt. This is the process to understand the ambiguities and this is the way to understand the series of different interpretations but not the solutions.

\subsection{Loss of Communication and Ambition}

Communication has lost its importance as so called individuality has taken its place. Human beings are unable to communicate with each other and they are desperate to talk yet they don't know what to say and how to say. 
They are incapable to take any responsibility and for them ambition, hard work, sensibility is no more than a joke. As in The American Dream, Mrs. Barker talks about Ambition quite disdainfully:

Mrs. Barker: Ambition! That's the ticket. I have a brother who is very much like you Daddy....ambitious. Of course, he is a great deal younger than you; he is even younger than I am......if such a thing is possible. He runs a little newspaper. Just a little newspaper...... but he runs it. He's the chief cook and bottle washer of that little newspaper which he calls Village Idiot. He has such a sense of humor; he is so selfdeprecating, so modest. And he would never admit it himself, but he is the Village Idiot (Albee, 1961).

This is how ambition, dream and inspiration have been taken in American society. Those who work hard, ambitious and determined they will be considered idiots. With the help of Aporia, language has been decentralized to explore the meaninglessness of existence. Every positive human value has been reduced to a joke. American people are quite unable to feel anything in their life rather their lives are quite mechanical and futile. Jerry demonstrates this futility, meaninglessness and bleakness in Albee's The Zoo Story:

I have no longer the capacity to feel anything. I have no emotions; I have been drained, torn asunder...disemboweled. I have, now, only person......my body......my face. I use what I have ......I let people love me ......I accept the syntax around me, for while I know I cannot relate.... I know I must be related $t o$. I let people love me. I let them draw pleasure from my groin...... from my presence...... from the fact of me.......but that is all it comes to. As I told you, I am incomplete ...... I can fell nothing, I can see nothing (Albee, 1958).

Jerry projects the true picture of American society as people feel nothing; they are morally, ethically and spiritually impotent or dead. They know that they are incomplete yet they don't want to complete themselves. They are happy with their perplexity, ambiguity, and vagueness. This happiness is quite symbolic as this is not the happiness in true sense of the word. Their happiness is another expression for their immunity because they feel nothing and they can see nothing as they are morally and spiritually blind. Aporia also explores one more point that language has lost its importance and American Dream is losing its place.

American Dream once was celebrated as equality, fraternity and pursuit of happiness by those who believed in it. As James Truslow Adams mentions this in Epic of America:

It is not a dream of motor cars and high wages merely, but a dream of social order in which each man and each woman shall be able to attain to the fullest stature of which they are innately capable, and be recognized by others for what they are, regardless of the fortuitous circumstances of birth or position (Adams, 1931, p. 56).

\subsection{American Dream and Aporia}

According to Adams, American Dream means to attain capability, recognition, equality and justice but for modern American people American Dream is not very much attractive to them. Modern American playwrights lament on the loss of every value related to human existence and American Dream. They don't celebrate American Dream because they know that real American Dream cannot be found practically in modern \& postmodern American society. O'Neill mentions this lamentation in Great God Brown, "Man is born broken. He lives by mending. The grace of God is glue" (O'Neill, 1926, p. 134). O' Neill's point of view makes lot of issues evident and they are about the breakdown of human communication, disintegration, futility of human existence, inability of man to perform any duty and take responsibility and absence of ambition and purpose. All these issues have been discussed and analyzed with reference to Derridean Deconstructive term Aporia, which according to Seigal, is "A moment of undecidability; the inherent contradictions found in any text" (Seigel, 2009, para. 12). American dream, American society and values have been analyzed, explored, destructed, reconstructed and deconstructed with the help of Deconstruction. The main purpose of analyzing the issues regarding American Dream and American society with the help of Aporia is to explore the usage of language by Edward Albee in his different plays. Language used by Albee and different American playwrights during mid-twentieth century demonstrate the meaningless and purposeless life of American people. American people are leading a life like hollow men as there is no direction in their life. One more issue which Albee and other American playwrights have raised is the disability of males to take responsibility of their family and family values. They are neither morally nor spiritually strong to come forward and protect the familial values. Albee presents the characters of Daddy and Youngman in The American Dream and in The Sandbox to expose the crippled male stratum of American society. As Daddy needs proof of his masculinity all the time from Mommy and Youngman despite having all the strength and vigor are unable to do something creative. Language in these plays play an important as it explores the incapability of human being to exist in this world. O'Neill mentions this dilemma in Long Day's Journey into Night: 
It was a great mistake, my being born a man, I would have been much more successful as a seagull or a fish. As it is, I will always be a stranger who never feels at home, who does not really want and is not really wanted, who can never belong, who must be a little in love with death (O'Neill, 1941)!

So being born in American society is a mistake as males in America are incapable of doing anything creative and different.

Human beings in modern America are quite distant from each other; they are discontented and unhappy from their situation because they don't find any ray of hope and because American Dream has become nonexistent. Families are living together but with a sense of certain relentlessness, menace, hatred, distrust, disloyalty and revulsion. Family like Shepard's Buried Child is living together under one roof but unable to understand each other or love each other or even tolerate each other. Family life is very much there in Miller's Death of a Salesman yet the familial warmth, love and care do not exist because Willy Loman (Head of the family) understood the real American Dream whereas sons (Biff \& Happy) lead a futile and weak life. Though Loman believed in the true spirit of American Dream yet he fails to follow this. Linda, Willy's wife, believes that Willy is a great man because at least he tried to color his life with the American Dream:

I don't say he's a great man. Willie Loman never made a lot of money. His name was never in the paper. He's not the finest character that ever lived. But he's a human being, and a terrible thing is happening to him. So, attention must be paid. He's not to be allowed to fall in his grave like an old dog. Attention, attention must finally be paid to such a person (Miller, 1949).

Linda's belief in Willy and American Dream is quite evident because she knows that her husband worked hard to make lot of his dreams true but he failed because the capitalism, insensitivity and discontentment within the American society failed him. Willy Loman was not a great man and he tries hard to make his life happy and successful yet he failed. The meaning of family life is to strengthen and to understand each other. But family life in twentieth century America is not the real family life because family life and family feelings have been collapsed. As Albee's The American Dream and The Sandbox both present the names of strongest family relationships; Mommy and Daddy but their relationship does not complete the family rather it dissipates this unit. In The American Dream, Mommy and Daddy live under one roof yet they don't know the meaning of their relationship as they are cruel, insensitive and inconsiderate towards Grandma and the adopted twin who had been mutilated, disfigured and murdered by his so called adopted parents. Grandma gets unbearable for them and they want to get rid of her by sending her to old home. It seems quite a common scene in American society but this common scene is viewed in terms of getting rid of values, morality, essential goodness and above all American Dream. Getting rid of Grandma in both The American Dream and The Sandbox is an attempt to show that American Dream is no more important for American people as it cannot fulfill their needs and desires anymore and it is just like an obsolete and worn out object which should be thrown out of house as soon as possible.

\subsection{Deconstructive Terms and Edward Albee's The American Dream}

Two other deconstructive terms are quite important in interpreting different meanings of language used by Albee and other playwrights. Différance and Erasure are two deconstructive terms that have been used in the analysis of language. Former points out the combination of meaning and later focuses on the absence of meaning but both have one focal point and that is the fluidity, variability and changeability of meaning. Language in Albee's plays reveals the setting, environment and characters who are lost in American society and don't want to find a way to get out of the situation. In both The American Dream and The Sandbox, language exposes the inner weaknesses of the character as they are unable to take decisions. As Daddy needs confirmation all the time from Mommy about his strength and masculinity:

Daddy: Was I firm about it?

Mommy: Oh, so firm; so firm.

Daddy: And was I decisive?

Mommy: SO decisive! Oh, I shivered.

Daddy: And Masculine? Was I really masculine?

Mommy: Oh, Daddy, you were so masculine; I shivered and fainted (Albee, 1961).

These lines represent the ambiguity, confusion, and moral and ethical weakness of male stratum of society. Males are unable to protect the family because they are too weak to take any responsibility of their family. They are lost in the land of opportunity as in Miller's Death of a Salesman; Biff has lost on such a magnificent land: 
Willy: Biff is a lost man. In the greatest country in the world a young man with such a personal attractiveness got lost. And such a hard worker. There is one thing about Biff, he's not lazy (Miller, 1949).

Biff is a representative of young generation of postmodern American society as they are unable to find a place for themselves. He is like young man of Albee's The American Dream and The Sandbox who despite have all the strength and vigor are confused and uncertain about their future and their strength. Grandma in American tries to give him strength by saying that he is American Dream yet they don't know what American dream really is, "Yup. Boy, you know what you are, don't you? You're the American Dream, that's why you are. All those other people, they don't know what they are talking about. You ..... you are the American Dream" (Albee, 1961, p. 45).

Grandma is trying to make Youngman realize that he is the American Dream. This is something that old American Dream is making New American Dream realize its status and standing. Différance and erasure play an important role as they are projecting both the ambiguity and multiplicity of meanings. The multiplicity and ambiguity of meanings are prevalent in the theory of Deconstruction. Derrida states:

In language, there are only differences. Even more important: a Difference generally implies positive terms between which the Différance is set up; but in language there are only differences without positive terms. Whether we take the signified or signifier, language has neither ideas nor sounds that existed before the system, but only conceptual and phonic differences that have issued from the system (1979, p. 66).

This is what language is which is based on multiplicity of signs, meanings and interpretations. Language plays an important role in understanding the characters, environment, and settings and how all these components work together to provide variety of meanings.

Language is a character in the plays of Edward Albee as it reveals lot of interpretations and those interpretations uncover a variety of signs which help reader to draw a point of view of his own choice. Albee presents American Dream as a challenge to American people to realize, understand and comprehend the reality of dream. This is what he states in the preface to The American Dream:

The play is an examination of the American Scene and attack on the substitution of artificial for real, values in our society, a condemnation of complacency, cruelty, emasculation, and vacuity, it is a stand against the fiction that everything in this slipping land of ours is peachy-keen (Albee, 1961, p. 2).

\section{Conclusion}

As Edward Albee's and other American Playwrights' major works serve as an examination of American Dream (my Italics); this paper is an interpretation of American Dream in the perspective of Derrida's theory of Deconstruction. This is an attempt to understand the language and its various interpretations used by American playwrights to strengthen the point of view regarding language, American Dream and its interpretations. American Dream has been celebrated, denounced, accepted, rejected, and again brought in to consideration by different playwrights including Edward Albee. This research is significant in exploring the evolution of the American Dream as it figures out in the plays of Albee, O'Neil and Sam Shepard. The research offers a solid platform for the future researchers interested in the modern concept of American Dream and postmodern and post war disintegrated self in general and American Individual in particular. In the context of the older as well as the newer versions of American Dream, Albee's and other American playwrights' works have been analyzed and explored with reference to Derridean Theory of Deconstruction. These American Playwrights have also been referred to reiterate the discussion in order to expose the reality of the modern American life and the insufficiency and inadequacy of the American Dream. This may also help the researchers to trace back the ideology of the American Dream and its insignificance in today's world.

\section{References}

Adams, J. T. (1931). The Epic of America New York. NY: Simon.

Albee, E. (1958). The Zoo Story. London: Oxford.

Albee, E. (1959). The Sandbox. Boston, MA: Twayne.

Albee, E. (1961). The American Dream. New York, NY: Penguin.

Bloom, H. (1979). Living on. In B. Harold, D. Jacques, D. M. Paul, J. H. Miller \& H. Geoffrey (Eds.), Deconstruction and Criticism (1979). New York, NY: Seabury Press (Original Work Published in 1977).

Camus, A. (2006). Camus at Combat: Writing (pp. 1944-1947). Princeton, US: Princeton. 
Canaday, N. Jr. (1966). Albee's The American Dream and the Existential Vacuum. South Central Bulletin, 26(4), 1-33. https://doi.org/10.2307/3187819

Harris, W. V. (2013). Morality, Absurdity \& Albee. South West Review, 49(9). Retrieved March 15, 2013, from http://www.jstor.org

Johnson, C. E. (1968). In Defense of Albee. English Journal, 57(1), 60-75. https://doi.org/10.2307/812515

Lawrence, D. H. (1928). Lady Chatterley's Lover. London: Penguin

O’Neill, E. (1926). Great God Brown. London: Penguin.

O’Neill, E. (1956). Long Day's Journey into Night. London: Penguin.

O’Neill, E. (1991). A Conversation with Eugene O’Neill (1948). In E. W. Jackson (Ed.), Profiles: The Tragic Scene. Mississippi: Mississippi.

Selden, R., Widdowson, P., \& Brooker, P. (1985). A Reader's Guide to Literary Contemporary Theory (5th ed.). New York, NY: Pearson.

Seigel, K. (2009). Introduction to Modern Literary Theory. Retrieved April 13, 2013, from http://www.kristisiegel.com/theory.htm

Shepard, S. (1978). The Buried Child. New York, NY: Penguin.

Williams, T (1947). A Streetcar Named Desire. London, England: Penguin.

\section{Copyrights}

Copyright for this article is retained by the author, with first publication rights granted to the journal.

This is an open-access article distributed under the terms and conditions of the Creative Commons Attribution license (http://creativecommons.org/licenses/by/4.0/). 